\title{
GULLIVER AT HOME
}

\author{
A traveller's tale.
}

\section{BY ANATOLY BELILOVSKY}

W e think the aliens are watching all the time. It's safer this way. They don't take kindly to people who

upset Dad. Or me.

The aliens don't hold with cruelty.

Dad's eyes are open wide but there's no quiver in his chin, no tears gathering.

"Where are you, Nana?" he says.

"I'm here," I say. "I'm making your lunch."

"Is it ready?" he says.

"Almost," I say.

He paddles to the bathroom, turns on the light. I hear water running, splashing as he washes his hands. He never forgets. His grandma taught him well. He always said I looked like her, moved like her, even smelt like her, ever since I was a little girl, ever since he'd bounced me on his knee as I rubbed my hand over his whiskers, the times he spent his leave at home. And now I cook like her, too, make homemade egg noodles from dough rolled translucent-thin and too much bay leaf in the chicken soup. Once I got that right, there were no more puzzled frowns as he tasted his first spoon of the broth.

Trial and error.

After lunch, as always, he walks over to the library. That was the easy part: he'd recollected the books when he still had his mind, matching editions to memories of his childhood, and shelved each book himself. Now he pulls Gulliver's Travels, starts to read. His lips move as he sounds out each word.

Odd how his memory works since aliens brought him back. Or how it doesn't.

My father left for Saturn when I was in sixth grade. He'd been to the Moon more times than he could count, to Mars a few times, missed the Jupiter run but made

D NATURE.COM Follow Futures: @NatureFutures $f$ go.nature.com/mtoodm
Dad got to go, with six other astronauts. His ship broke contact just before the Jupiter slingshot. Two days later, it reappeared in low Earth orbit, with only Dad on board.

With most of Dad, to be pedantic.

he ever exchanged with my mother? Every smell, every taste, every heartache, every joy?

It wasn't hard to love my father, growing up; I rarely saw him. I think my mother loved him, maybe for the same reason. She cried the first time she looked into his eyes and found a stranger looking back; Dad took her hand and whispered, "Why are you crying, lady?” Mom pulled away and ran, sobbing, from the room, and then a while later she tried to come back, but the aliens stopped her. That's pretty impressive, too: one moment she was moving, the next she wasn't.

I wish we knew what the aliens look like.

Some people think my father saved the world. They think the aliens stripped his mind, found it good and decent, and rebuilt it as best they could. They think they left us mostly alone because of what they found in his memories. But what they did to my father, whatever they did to the other six we still don't know what happened to them - if minds so cold, so ruthless,

The aliens had his childhood home reconstructed: one moment there was nothing, the next, there it was. I still don't know what's more impressive, the speed, or how well it matched Dad's memories. It was a quadrangle with a central courtyard, three storeys high, ground-floor flats with entrances from the yard, all others from balconies that ring the inside walls. He goes out there sometimes, looks at a square of sky, walks round the second-floor balcony, never knocking on any of the doors, never entering the stairwell.

He built a tent several times on warm days, from sheets and clothesline, dragged pillows inside and lay there playing with his toys. I have an old black-and-white photo of him on that balcony; the alien reconstruction is so perfect, I can match the photo exactly to cracks in plaster.

Did aliens get every memory of Dad's? Every last thing he ever saw? Every word so - alien - felt an affinity to my father, what does it say about him?

I wonder about the other astronauts. What fault condemned them?

Gulliver's Travels. My father reads it every day; he never gets past Lilliputians. He read parts of the book aloud to me when I was little, and later I dreamt of being a giant among little people.

Doesn't everyone?

Is everyone cruel to Lilliputians in their dreams?

Or everyone but my father?

Anatoly Belilovsky was born in what is now Ukraine, learnt English from Star Trek reruns, worked his way through a US college by teaching Russian while majoring in chemistry, and has, for the past 30 years, been a paediatrician in New York, in a practice where English is the fourth most commonly spoken language. 